\title{
A Case Report of Elderly Woman with Supraventricular Tachycardia associated with Intracranial Bleeding
}

\author{
Raymond Pranata ${ }^{1}$, Veresa Chintya ${ }^{2}$, Emir Yonas ${ }^{3}$, Vito Damay ${ }^{1,4}$
}

'Faculty of Medicine, Universitas Pelita Harapan, Tangerang, Indonesia ${ }^{2}$ Sanjiwani General Hospital, Gianyar, Indonesia

${ }^{3}$ Faculty of Medicine, YARSI University, Jakarta, Indonesia ${ }^{4}$ Department of Cardiology and Vascular Medicine, Siloam Hospital Lippo Village, Tangerang, Indonesia
Background The neurogenic cardiac injury is related to brain injury-induced catecholamine and neuro-inflammatory responses and is more likely in those with the most severe neurological insult.

Case Report A 78 years-old female presented to the emergency department after being found lying on the floor with a laceration on the head. On physical examination GCS 3, $\mathrm{BP}$ I 40/90 mmHg, HR I $90 \mathrm{bpm}$, respiratory rate $25 \mathrm{x} /$ minute. $\mathrm{PMH}$ of hypertension and diabetes were denied. ECG showed supraventricular tachycardia of I 86 bpm. Laboratory exams showed hyponatremia, hypokalemia, and leukocytosis. CT scan revealed subarachnoid hemorrhage, intracerebral hematomas, chronic subdural hematoma, midline shift and subfalcine herniation. The systemic catecholamine 'storm' driven by the central neuroendocrine axis massively increases sympathetic outflow, activates the adrenal gland and may lead to arrhythmia. Increased ICP, Midline shift, and subsequent physical compression of the brainstem and hypothalamic autonomic centers can trigger catecholamine responses that could instigate an arrhythmia. Suboptimal cardiac output and cerebral perfusion worsen secondary brain injury leading to a worse prognosis. Since cardioversion failed, amiodarone was administered. Cardioversions failed to convert to sinus rhythm and amiodarone was administered. Therapy to reduce intracranial pressure was also administered. The patient passed away 4 hours after admission.

Conclusion Arrhythmia related to brain injury may lead to suboptimal cerebral perfusion and leads to further autonomic derangements leading to a vicious cycle of cerebral and cardiovascular injuries. This condition should be accounted for swiftly to prevent secondary brain injuries and myocardial ischemia.

(Indonesian J Cardiol. 2017;38: I79-84)

Keywords: supraventricular tachycardia, brain injury, cerebral perfusion, brain hemorrhage 


\title{
Takikardi Supraventrikular yang Berhubungan Dengan Perdarahan Intrakranial pada Seorang Perempuan Lanjut Usia: Sebuah Laporan Kasus
}

\author{
Raymond Pranata1 ${ }^{1}$ Veresa Chintya ${ }^{2}$, Emir Yonas ${ }^{3}$, Vito Damay ${ }^{1,4}$
}

Latar Belakang Respons katekolamin dan radang terhadap cedera otak menyebabkan cedera jantung neurogenik yang lebih sering terjadi pada kerusakan neurologis yang berat.

Laporan Kasus Seorang perempuan 78 tahun datang ke IGD setelah ditemukan tergeletak di lantai dengan robek pada kulit kepala. Pada pemeriksaan fisik ditemukan GCS 3, TD 140/90 mmHg, detak jantung $190 \mathrm{kali} /$ menit, laju pernafasan $25 \mathrm{kali} /$ menit. Riwayat hipertensi dan diabetes disangkal. EKG menunjukan takikardia supraventrikular takikardi 186 kali/menit. Pemeriksaan laboratorium menunjukan hiponatremia, hipokalemia dan leukositosis. CT scan menunjukan perdarahan subaraknoid, perdarahan intraserebral, perdarahan subdural kronis, midline shift dan herniasi subfalcine. Badai katekolamin sistemik yang dicetuskan oleh aksis neuroendokrin pusat meningkatkan outflow simpatetik yang mengaktifkan kelenjar adrenal dan menyebabkan aritmia. Peningkatan tekanan intrakranial, midline shift, dan penekanan batang otak serta pusat autonomik hipotalamus dapat mencetuskan respon katekolamin yang dapat menyebabkan aritmia. Curah jantung yang tidak optimal dan perfusi otak yang buruk menyebabkan cedera otak sekunder yang mengarah pada prognosis yang buruk. Karena kardioversi gagal merubah irama menjadi sinus maka amiodaron diberikan. Pengobatan untuk menurunkan tekanan intrakranial juga diberikan. Pasien meninggal 4 jam setelah masuk rumah sakit.

Kesimpulan Aritmia yang berhubungan dengan cedera otak dapat menyebabkan perfusi otak yang suboptimal serta menyebabkan ketidakteraturan otonom dan menyebabkan lingkaran setan kerusakan otak dan jantung-pembuluh darah. Hal ini harus segera ditangani untuk mencegah cedera otak sekunder dan iskemi miokardial.

(Indonesian J Cardiol. 2017;38:179-84)

Kata kunci: takikardia supraventricular, cedera otak, perfusi otak, perdarahan otak

'Fakultas Kedokteran, Universitas Pelita Harapan, Tangerang, Indonesia, ${ }^{2}$ Rumah Sakit Umum Sanjiwani, Gianyar, Bali, Indonesia, ${ }^{3}$ Fakultas Kedokteran, Universitas YARSI, Jakarta, Indonesia, ${ }^{4}$ Departemen Kardiologi dan Kedokteran Vaskular, Siloam Hospital Lippo Village, Tangerang, Indonesia

\section{Correspondence:}

dr. Raymond Pranata, Faculty of Medicine, Universitas Pelita Harapan, Tangerang, Banten, Indonesia. E-mail: raymond_pranata@hotmail. com

\section{Introduction}

Cardiovascular complications are common after brain injury with a consequent increase in morbidity and mortality, although most patients who die do so because of their brain injury. ${ }^{1,2}$ Abnormalities includes hypertension, hypotension, electrocardiography (ECG) changes, cardiac arrhythmias, the release of biomarkers of cardiac injury, and left ventricular dysfunction. Neurogenic cardiac injury is related to brain 
injury-induced catecholamine and neuroinflammatory responses and is more likely in those with the most severe neurological insult. ${ }^{1}$ intracranial pressure. However, despite these measures, her condition deteriorated and she passed away 1 hours after admission.

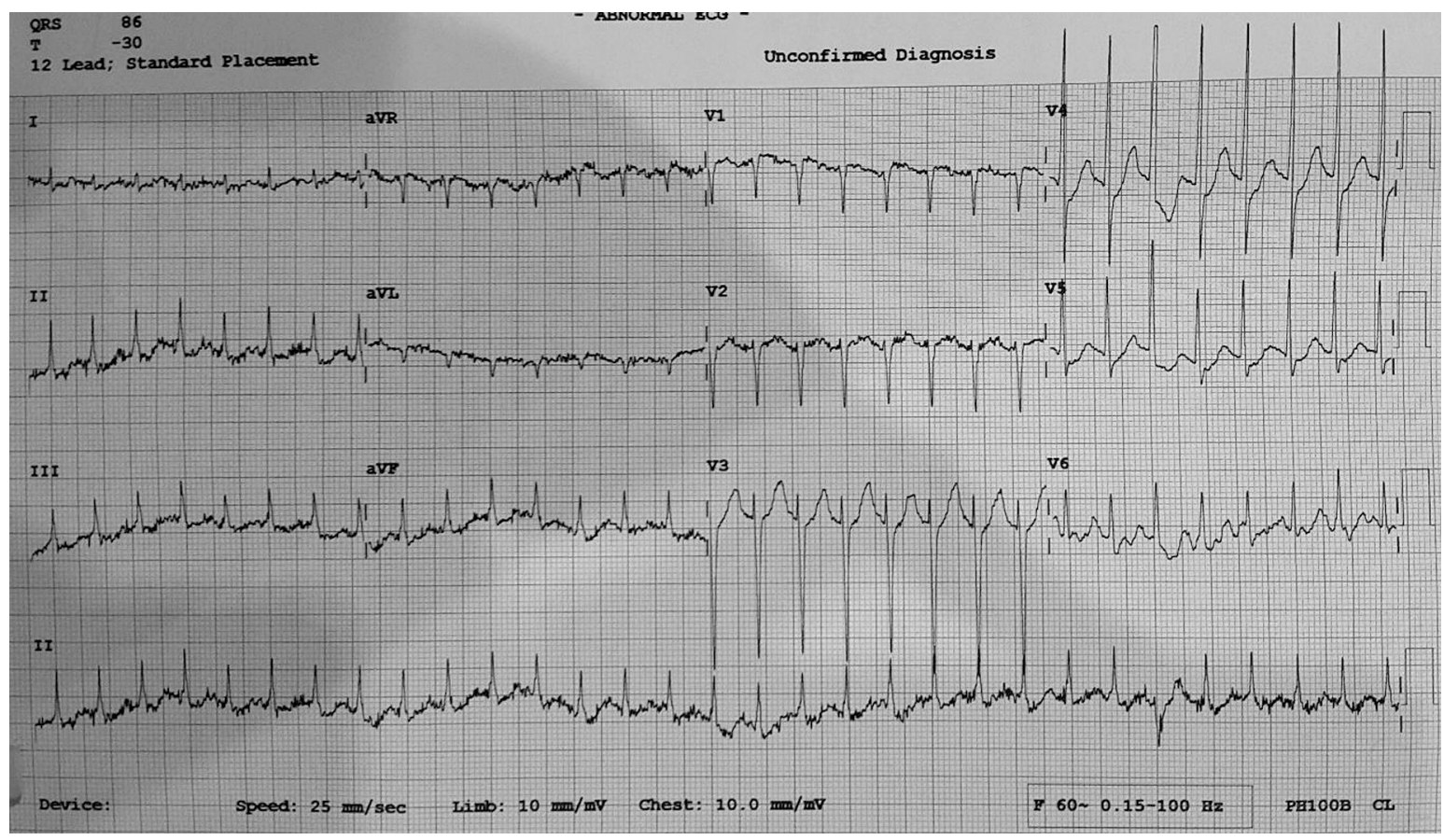

Figure 1. Patient's 12 lead ECG

\section{Case Report}

A 78 years-old female presented to the emergency department after being found lying on the floor with a laceration on the head. Her medical and family history was unremarkable. On admission, physical examination revealed Glasgow comatose scale E1V1M1 3, BP 140/90 $\mathrm{mmHg}, \mathrm{HR} 190 \mathrm{bpm}$, respiratory rate 27x/minute. The cardiorespiratory examination was within normal limits. ECG showed supraventricular tachycardia (SVT) of $186 \mathrm{bpm}$. Laboratory exams showed hyponatremia 129 $\mathrm{mmol} / \mathrm{L}$, hypokalemia $2.9 \mathrm{mmol} / \mathrm{L}$, and leukocytosis $22.700 \times 10^{\wedge} 3 \mathrm{u} / \mathrm{L}$. Chest X-Ray revealed elongated aorta. Computed Tomography scan of the head revealed subarachnoid hemorrhage, intracerebral hematomas, chronic subdural hematoma, midline shift and subfalcine herniation. Synchronized cardioversions of 50 and 100 joules failed to convert the patient to sinus rhythm and amiodarone was administered. Therapy to reduce intracranial pressure was also administered. Correction of hyponatremia and hypokalemia was also done. Mannitol was administered to reduce

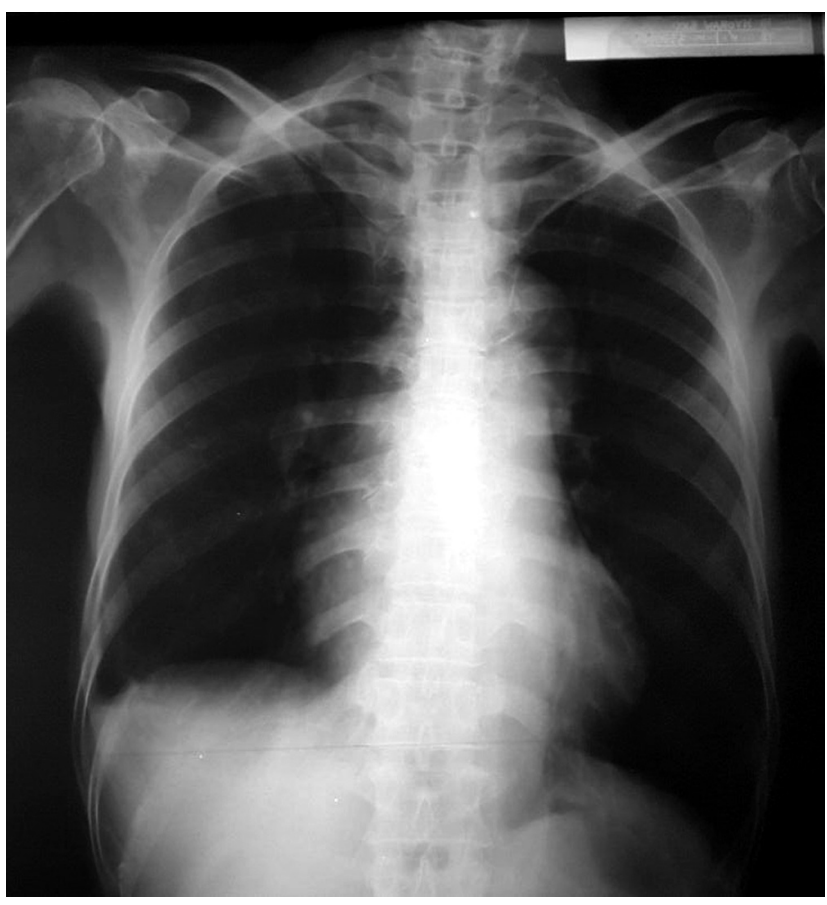

Figure 2. Patient's Anteroposterior Chest X-Ray 


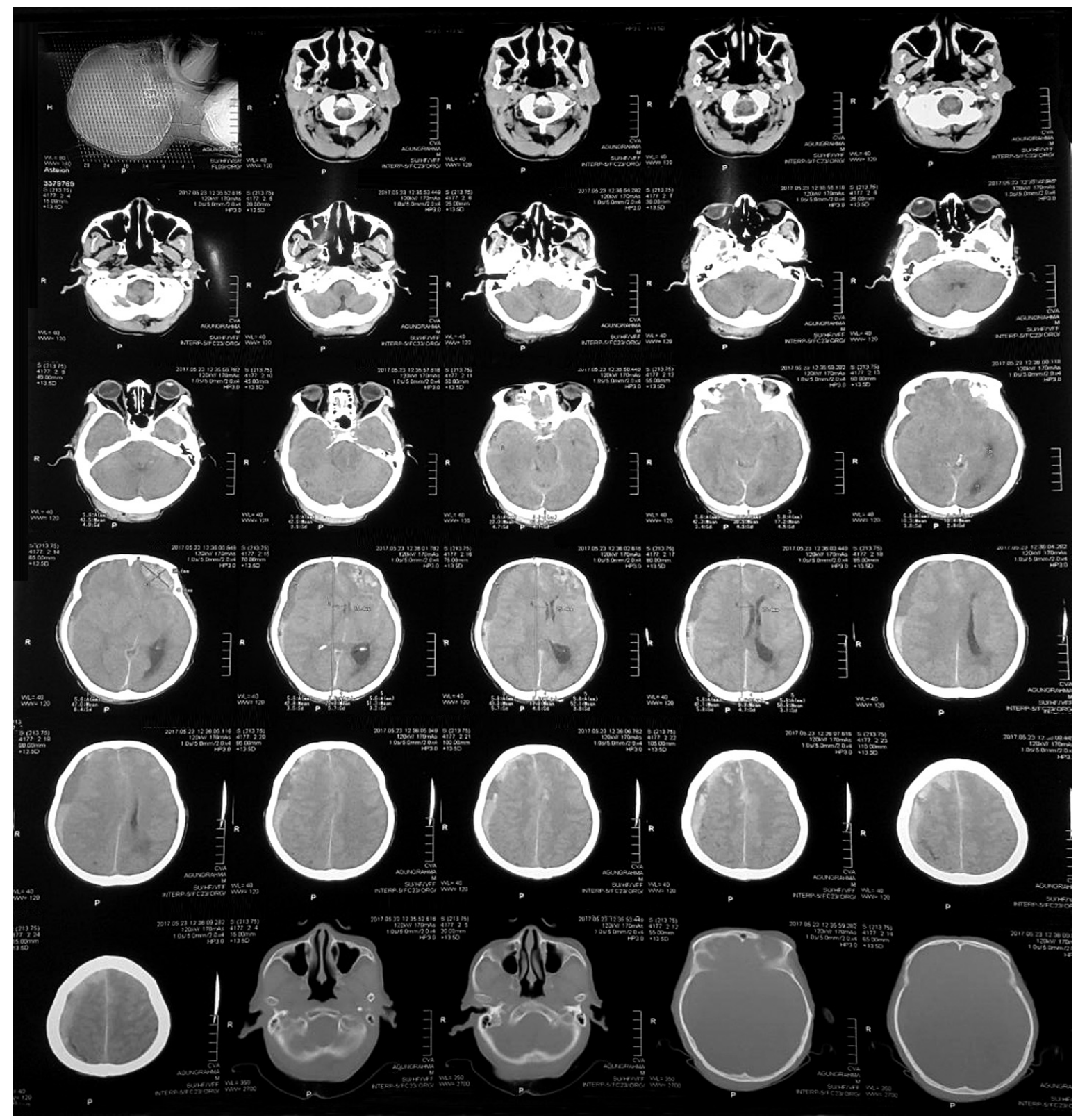

Figure 3. Patient's CT-Scan of the head

\section{Discussion}

Supraventricular tachycardia is defined as arrhythmias originating from above ventricle. It is a broad term comprising of sinoatrial nodal reentry tachycardia (SANRT), atrial tachycardia, atrial flutter, atrial fibrillation, atrioventricular nodal reentry tachycardia (AVNRT), atrioventricular reentry tachycardia (AVRT), and paroxysmal junctional tachycardia. Enhanced automaticity, re-entry and triggered automaticity are the underlying mechanism of arrhythmia which may differ in characteristics and treatment preference. This patient had regular narrow QRS complex tachycardia with no visible $\mathrm{P}$-wave which might be obscured by baseline artifact. The differential diagnosis in such patients includes AVNRT (most common), AVRT, SANRT, sinus tachycardia and atrial flutter. Adenosine or vagal maneuver test plays an important role in such patient who is hemodynamically stable. In those who have their arrhythmia terminated after the test signifies AVNRT, orthodromic AVRT, atrial tachycardia, and SANRT. Conversely, in those 
with persistent arrhythmia atrial tachycardia, atrial flutter and SANRT are the most common causes. If tachycardia terminates with $\mathrm{P}$ after the last QRS, AVNRT or AVRT is the most likely diagnosis while atrial tachycardia is unlikely. Temporarily lowered heart rate may unmask the otherwise non-visible $\mathrm{P}$ waves facilitating diagnosis. Adenosine or vagal maneuver test relies on AV nodal blocking mechanisms and is more likely to terminate those with reentry mechanism and in those with enhanced automaticity, such tests are more likely to slow the heart rate but not terminating the arrhythmia. The systemic catecholamine 'storm' driven by the central neuroendocrine axis massively increases sympathetic outflow, activates the adrenal gland and may lead to arrhythmia. ${ }^{1}$ Damage to the insular and hypothalamus resulted in complex cascade of events, including activation followed by dysfunction of the autonomic nervous systems and an intense inflammatory response, which have major adverse effects on the heart. ${ }^{1}$ It may also cause direct injury to myocardium. ${ }^{3}$ Hemorrhages, increased intracranial pressure (ICP), midline shift, and subsequent physical compression of the brainstem and hypothalamic autonomic centers can trigger catecholamine responses that could instigate arrhythmia in this patient. ${ }^{2}$ This means that the arrhythmia in this patient is most probably caused by enhanced automaticity due to systemic catecholamine storm is driven by central neuroendocrine axis. Due to high circulating catecholamine for up to 10 days cardiac dysfunction may persist for a protracted period. Suboptimal cardiac output and cerebral perfusion may worsen secondary brain injury leading to a dismal prognosis. ${ }^{4}$ In patients with increased intracranial pressure (ICP), the higher mean arterial pressure is needed to maintain cerebral perfusion pressure (CPP). SVT may jeopardize this by limiting cardiac output especially if condition deteriorates further and affect blood pressure. The basis for cardioversion in this patient is to prevent secondary brain injury rather than blood pressure, signs of heart failure or loss of consciousness. Loss of consciousness in this patient was predominantly caused by intracranial hemorrhage. Even though the cerebral perfusion is not usually impaired in SVT without structural heart disease, the presence of high ICP is our consideration to optimize the cardiac output before further cardiac deterioration (due to any cause but especially secondary brain injury) compromise perfusion leading to more severe cardiac and cerebral injury. 12-lead ECG should be repeated at $24 \mathrm{~h}$ intervals until any abnormalities have resolved. There is no specific treatment for brain injury induced cardiac arrhythmia, correction of electrolyte disturbances and management of the underlying intracranial pathology is the most effective way to prevent and treat the arrhythmia. ${ }^{1}$ Hence correction of hyponatremia, hypokalemia and reducing intracranial pressure are integral to the treatment of this patient. This highlights the importance of mannitol administration to reduce intracranial pressure and the necessity of neurosurgical consult. To maintain optimal CPP in this patient ICP monitor is necessary for precise calculation. ${ }^{5}$ Since cardioversion failed, the antiarrhythmic drug amiodarone was administered in an attempt to convert SVT to sinus rhythm. This is understandable because the mechanism of arrhythmia in this patient was most likely due to enhanced automaticity due to catecholamine storm which is rather difficult to terminate using electrical cardioversion. Another option that may be effective in this patient is to use AV nodal blocking agent which may act rapidly and maintained for a longer period of time. The prognosis was bleak and the patient passed away despite maximum effort.

\section{Conclusion}

Arrhythmia related to brain injury may lead to suboptimal cerebral perfusion and leads to further autonomic derangements leading to a vicious cycle of cerebral and cardiovascular injuries. This condition should be accounted for swiftly to prevent secondary brain injuries and myocardial ischemia.

\section{Abbreviations}

CPP: cerebral perfusion pressure

ECG: Electrocardiography

ICP: increased intracranial pressure

SVT: supraventricular tachycardia

\section{Ethics Approval}

Not Applicable

\section{Availability of data and material}

The datasets supporting the conclusions of this article 
are included in the article

\section{Competing interests}

The authors declare that they have no competing interests

\section{Funding}

No source of funding

\section{Authors' contributions}

RP admitted, evaluate and treat the first patient. RP, VC, and EY also planned and drafted the manuscript. VAD supervised and gave expert advice regarding the manuscript. All authors read and approved the final manuscript

\section{Acknowledgements}

Not Applicable

\section{References}

1. Gregory T, Smith M. Cardiovascular complications of brain injury. Contin Educ Anaesth Crit Care Pain 2012;12(2):67-71. https://doi.org/10.1093/bjaceaccp/mkr058

2. Mahmoud AN, et al. Cardiovascular Abnormalities and inHospital All-Cause Mortality in Patients with Spontaneous Sub-Arachnoid Hemorrhage: An Observational Study. Cardiol Ther 2017;6(1):33-40. https://doi.org/10.1007/s40119-0160076-0

3. Lim H.B., Smith M. Systemic complications after head injury: A clinical review. Anaesthesia 2007;62:474-482. doi: 10.1111/j.1365-2044.2007.04998.x.

4. $\quad$ Meng L.Z., Hou W.G., Chui J., Han R.Q., Gelb A.W. Cardiac output and cerebral blood flow. Anesthesiology 2015;123: 1198-1208. doi: 10.1097/ALN.0000000000000872

5. Kirkman MA, Smith M. Intracranial pressure monitoring, cerebral perfusion pressure estimation, and ICP/CPP-guided therapy: a standard of care or optional extra after brain injury? Br J Anaesth 2014; 112(1):35-46. doi: 10.1093/bja/ aet 418 . 